\title{
Sustainability in architectural heritage: review of policies and practices
}

DOI 10.1515/otmcj-2016-0007

Received February 5, 2016; accepted August 29, 2016

\begin{abstract}
If sustainable development goals are to be achieved, it is necessary to consider refurbishment of architectural heritage buildings as well! As just $1 \%$ of buildings in the European Union have been built since 2006, it is essential to turn towards refurbishment of existing buildings if goals of sustainable development are to be achieved. Therefore, this article explores the ways in which sustainable development in construction is encouraged and achieved, especially concentrating on architectural heritage buildings. The idea of sustainable development revolves solely around carbon emissions, and therefore, historic buildings in Europe face the key issue of sustainability. Recently, there has been an increasing interest in reusing existing buildings through refurbishment and adaptive reuse where possible, as building reuse should offer environmental savings over demolition and new construction. In addition, despite popular belief, older buildings are capable of adapting to the new energy efficiency norms. This study explores the possibilities of encouraging complete refurbishment (including both sustainable renovation and strengthening) of historical buildings by exploring incentives used in Europe, the USA, Canada and New Zealand. Based on the literature review and best practices, the article concludes with recommendations on how to increase the positive investment flow of private capital into architectural heritage buildings, thus ensuring both preservation of heritage and achievement of sustainable development goals. The findings help both the user of the initiative on gaining insight into the intervention process that can be expected, as well as the local and regional governments interested in boosting adaptive reuse and refurbishment of existing buildings in order to achieve sustainable development goals.
\end{abstract}

Keywords: sustainable development, architectural heritage, refurbishment, strengthening, complete refurbishment, sustainability, financing, policy, regulatory framework

*Corresponding author: Zvonko Sigmund, Faculty of Civil Engineering, University of Zagreb, Zagreb, Croatia, E-mail: zsigmund@grad.hr

\section{Introduction}

This study explores the ways in which sustainable development in construction is encouraged and achieved, especially concentrating on architectural heritage buildings. The article develops around the idea that adaptive reuse and refurbishment of existing buildings is inevitable if sustainable development goals are to be achieved, whereby structural safety and strengthening of historical buildings are not to be left out when planning these major renovations. The findings reported here are based on international best practices and are intended for Croatian building owners and government, but the same principles are applicable in many countries of Europe, such as Greece, Belgium, Sweden and so on.

The potential for refurbishment of homes and the adaptive reuse of cultural heritage buildings is significant due to the current composition of the building stock in Europe and the preferred attitude of the public towards the older stock (Sodagar 2013). Despite popular belief, older buildings are capable of adapting to the new energy efficiency (EE) norms; therefore, the challenge is to achieve the wanted effect without damaging the architectural and historical value of buildings as well as retain the feasibility of investment (Ding 2013). The benefits of choosing refurbishment over new build have also been brought into focus, as the existing buildings will comprise the majority of the total building stocks for years to come and hence will remain responsible for the majority of greenhouse gas emissions from the sector (Smith 2007). Adaptive reuse, however, bypasses the wasteful process of demolition and reconstruction. This environmental benefit, combined with the energy savings, reduction in carbon emissions as well as the social and economic advantages of recycling a valued heritage building, make reuse an essential component of sustainable development.

Croatian building stock is made of 35\% masonry buildings that were built during the period from the 1860s until the 1920s. These were mainly built according to the Austrian building regulations of that time and are 
characterized by masonry-bearing walls with masonry vault or wooden beam floors. These buildings, as such, are in most cases vulnerable to seismic activities that can be expected in Croatia and are not in accordance with contemporary EE provisions (Sigmund 2014).

Therefore, literature review was conducted especially concentrating on the possibilities of boosting the interest for investments in building safety-increasing and sustainable refurbishment measures. Additional care was given to finding measures that cover sustainable refurbishment and strengthening for architectural heritage buildings, as buildings built during the studied period are in most cases listed as heritage buildings.

Most of the important governmental offices in Croatia are situated in historical buildings (Sigmund 2014), and according to European Parliament directives 2012/27/EU and 2010/31/EU, all European countries are to promote EE in both existing and new buildings and governments are to renovate at least $3 \%$ of total governmentally owned buildings up to the minimum energy performance set by the government itself (EU Parliament Directive [EUPD] 2010; EUPD 2012). Additionally, research showed that seismic strengthening upgrades tend to cost no more than $3 \%-5 \%$ of the whole renovation investment, including strengthening of masonry buildings (Sigmund 2014). For instance, the cost of seismic strengthening for masonry buildings should not overshoot the $150 € / \mathrm{m}^{2}$ mark (Dolce 2012; Maffei et al. 2006). Not doing so, however, can put the whole investment and human lives at risk.

If refurbishment of a building is considered as the operation that occurs when a range of building activities need to be undertaken together, often due to a combination of obsolescence and deterioration (Ashworth 1996), then sustainable refurbishment can be achieved when all the principles of sustainable energy-efficient building design are implemented where appropriate (Sodagar 2013). In most cases, these older buildings usually cannot provide the type of comfort considered as modern. In these cases, these homes and buildings should be adapted to the concurrent needs of their users to retain social usefulness. In some cases, this even means changing the initial use of the building-provided space (Yung and Chan 2012). This is considered to be adaptive reuse of existing buildings.

Based on the stated facts, it should be pointed that when planning major renovations, such as sustainable refurbishment and adaptive reuse of buildings, strengthening and other protective measures should not be left out. However, the author discovered that there are no systematic incentives aiming to encourage strengthening, retrofitting or upgrading of historical buildings in Croatia at all, and Europe is just starting to adjust to the requested EUPDs (Kim and Park 2013).

If sustainable development is considered to have the aim of ensuring a better quality of life for everyone, now and for future generations, which - as one of the three pillars of sustainable development - includes "protection and enhancement of the environment" (Pickard 2010), then ensuring the existence of architectural heritage buildings by strengthening and promoting protective interventions against natural and man-made hazards is on the same course.

\subsection{Research objectives}

It should be pointed out that the intention of the author is not to promote another EE or sustainable development principle, but to research possibilities to promote complete refurbishment measures, which include repair of building, strengthening and sustainable refurbishment for older Croatian building stock. As the governmental initiatives tend to be promoted usually in similar ways, a number of best practices, on both heritage upkeep measures and EE incentives, are reviewed concentrating on incentives/stimulative measures and the way these measures are enabled. The research was conducted aiming to find out which financial measures are best used for which purpose and, additionally, what is the best way to plan and start the sustainable refurbishment or adaptive reuse process.

This study explores the possibilities of encouraging complete refurbishment (including EE and structural safety) of historical buildings by exploring incentives used in Europe, the USA, Canada and New Zealand. As a conclusion, recommendations to increase the positive investment flow of private capital into architectural heritage buildings are presented, thus ensuring both preservation of heritage and sustainable development goals. The recommendations are based on the knowledge gained on best practices presented in this article and during the research conducted as part of the author's $\mathrm{PhD}$ thesis research. The findings also help the user of the initiatives on gaining insight into the intervention processes that need to be executed when the decision is made to invest into one's real estate. These findings can be used by local and regional governments interested in boosting adaptive reuse and complete refurbishment of existing buildings in Croatia, but these can also be applied to any country. 


\section{Financial incentives and principles}

It is undeniable that in most countries, EE incentives exist. Yet, these are generally only oriented towards control of energy consumption. For instance, California has been making good efforts since the 1970s to decrease energy consumption, whereby both private and public buildings are obliged to invest into energy-efficient solutions in their buildings. For these EE measures, users can receive grants or co-financing (Thomas 2016). Germany, on the other hand, provides the investors that are interested in investing into EE loans with low or even negative interest. The government hereby stimulates EE investments through a governmentally owned bank (KfW Bankgruppe) (Thomas 2016).

\subsection{Best practices in dealing with existing buildings}

Generally, EE measures can be categorized as measureoriented projects, whereas interventions on historical buildings usually demand the whole-house-oriented project, as sustainable refurbishment in historical buildings requires a whole set of other investments besides EE. If refurbishment is a building operation that occurs when a range of building activities need to be undertaken together, often due to a combination of obsolescence and deterioration (Ashworth 1996), then an existing building should be observed as a several-staged project, in which ensuring the stability and safety of the building is the first stage. Following the structural strengthening, sustainable refurbishment and adaptive reuse can be considered.

Thus, buildings that are to be refurbished present an opportunity to add value and reduce the carbon cost of buildings through improved energy-efficient design. As complete financial incentives covering structural strengthening, upkeep and EE works for heritage buildings do not exist, except partially in the USA, best stimulative practices on EE, structural safety and refurbishment (partial incentives) are going to be reviewed further on.

\subsubsection{Austria}

A major mission was undertaken by "Wiener Wohnen" (a company responsible for managing and restoring social housing in Vienna) when they decided to renovate social housing buildings (Lorbek et al. 2013). Yet another major breakthrough that should not go unmentioned is the creation of guidelines on EE renovation measures that are allowed on built heritage buildings, published by the Austrian Heritage Protection Agency (Bundesdenkmalamt 2011).

\subsubsection{The UK: whole-house incentives}

According to the Department of Energy and Climate Change (DECC), besides the already existing incentives for renewable heat generation and small-scale low-carbon electricity generation, the government is considering introducing subsidies for expensive measures, which are to be paid either through taxes or through energy bills, under the presumption that the whole of society can benefit from the wider benefits such as reduced carbon emissions and the lower cost of meeting renewable energy targets (DECC 2009).

In the UK, there is a possibility of applying for the Architectural Heritage Fund, which provides low-interest loans to assist the work of Building Preservation Trusts.

\subsubsection{New Zealand's policies for existing houses}

New Zealand's government has, as a first step, introduced higher EE standards for existing and new commercial buildings. Thus, the EE of existing buildings becomes the obligation of the owner. The Energy Efficiency and Conservation Authority subsidizes energy improvement of rental homes with 55\% subsidy, according to Warnock (2007).

Additionally, New Zealand introduced obligatory insurance of all real estates against earthquakes. These insurance policies cost about $5 \mathrm{NZD} /$ month and cover complete rebuilding costs in case of an earthquake (Earthquake Engineering Research Institute [EERI] 2010).

\subsubsection{Los Angeles Adaptive Reuse Program and Ordinance}

The Los Angeles (LA) Adaptive Reuse Program has been running for several years as part of a strategy to regenerate large sections of the city. To assist the programme, the Adaptive Reuse Ordinance was also produced to streamline the application process and provide more flexibility in meeting building code and zoning requirements. Buildings being adapted still have to satisfy 
planning and building code requirements but are subject to exemptions from compliance, which the LA City Council felt would encourage conversion of underutilized commercial buildings to more productive uses. The construction guidelines (Building and Safety) also provide flexibility in meeting structural and fire requirements. The mentioned ordinances introduced financial incentives to provide income and property tax reductions and construction incentives such as tax deductions and continuous incentives to continue preserving historic property (Bullen and Love 2009).

\subsubsection{Romanian incentives on seismic protection}

Romanian incentive is one of the most interesting occurrences, namely, the Romanian government prescribed an obligatory building evaluation for the building prioritization list creation. The buildings are then classified in accordance with their building typology, region, construction period and their seismic risk. Buildings classified as first category of risk have to be strengthened within 5 years. Strengthening works on the buildings whose owners are listed as low-income owners are fully funded by the government. For other buildings, the government offers governmentally subsidized financing options (Lungu and Arion 2006).

\subsubsection{The Netherlands}

Similarly, in the Netherlands, the National Restoration Fund provides low-interest loans. Thus, an owner may receive a grant in addition to tax relief and the remainder in the form of a low-interest loan to cover repair costs. Improvements such as the provision of modern utilities are only deductible in Germany and the Netherlands.

\subsubsection{Danish proactive policy}

The proactive policy operated by the Danish Historic Houses Owners Association, encompassing income tax relief, is designed to encourage systematic maintenance of architectural heritage buildings by private owners, thus preventing the decay of architectural heritage buildings.

Similar to Germany, in Denmark, low-interest loans are available from a revolving fund administered by the National Forest and Nature Agency to finance restoration activities in excess of a grant award.

\subsection{Financial incentives used}

Generally, a number of different financial initiatives exist as governments are constantly trying to improve the efficiency of their sustainable development initiatives. As typical initiative types, tax deductions, tax rebates, exemptions or tax credits are used. These measures reimburse the investment through different tax corrections, evading the need for governmental financing. Grants and subsidies, however, are the most common form of government funding. Subsidies are usually financed directly to the user of finances (merchant, contractor, etc.) whereby just a part of the whole cost is covered, whereas grants are used for investment "risk" transferral, where the whole cost for a particular product is covered (e. g. solar water heater). Loans are provided in the form of low-interest or no-interest loans directly by the government for a specific purpose only. Third-party financing in EE upgrades is usually used in cases where the investor transfers his/ her rights and investment to the third party, which then executes the whole upgrade and finances the investment from the governmental supports and the difference in the monthly bills until the whole investment is covered. In the case of architectural heritage buildings, these investments are usually achieved through transfer of development rights (TDRs) or donations, which are allowed in every country examined. The types of financial incentives available in Europe and the USA are shown in Table 1.

Tab. 1: Energy efficiency (EE) and built heritage (BH) financial incentive types used in Europe and the USA.

\begin{tabular}{|c|c|c|c|c|c|c|c|c|c|c|}
\hline \multirow{2}{*}{ Country } & \multicolumn{2}{|c|}{ Subsidies } & \multicolumn{2}{|c|}{ Tax } & \multicolumn{2}{|c|}{ Grants } & \multicolumn{2}{|c|}{ Loans } & \multicolumn{2}{|c|}{$\begin{array}{l}\text { Third } \\
\text { party }\end{array}$} \\
\hline & EE & BH & EE & BH & EE & BH & EE & $\mathrm{BH}$ & EE & BH \\
\hline Austria & - & $+\mathrm{P}$ & - & & + & $+\mathrm{P}$ & + & $+P$ & + & + \\
\hline Belgium & - & + & + & + & + & + & - & - & - & + \\
\hline Bulgaria & + & - & + & + & + & + & + & - & - & + \\
\hline Denmark & + & + & + & + & + & - & - & + & - & + \\
\hline France & - & - & - & + & + & + & + & - & + & + \\
\hline Germany & - & $+P$ & - & & + & + & + & + & - & + \\
\hline Italy & - & + & + & + & + & + & + & - & - & + \\
\hline The Netherlands & + & + & + & + & + & + & + & + & + & + \\
\hline Portugal & - & + & + & - & + & + & + & - & - & + \\
\hline Romania & - & - & - & - & + & + & - & + & - & + \\
\hline Spain & - & - & - & + & + & - & + & - & + & + \\
\hline Switzerland & - & + & + & - & + & + & - & - & + & + \\
\hline UK & - & + & + & + & + & + & + & + & - & + \\
\hline USA & + & + & + & + & - & - & - & - & + & + \\
\hline
\end{tabular}

Note: +, available; -, information or incentive not available; $+P$, initiative available on provincial level. 


\section{Research findings}

\subsection{Financial incentives}

\subsubsection{Grants, low-interest loans and guaranteed loans}

The majority of the analyzed countries provide a scheme of grant for the repair work of architectural heritage buildings ranging from $20 \%$ to $90 \%$ of eligible repair costs. These depend on the country, category of owner, property-generated revenue and the level of public access that may be required if substantial financing is required. Although quite a new type of incentive, Belgium, France and the Netherlands provide additional grant aids to cover ongoing maintenance costs. Thus, heritage owners are encouraged to stay in their realty and additionally, in the long run, large governmental investments can be avoided.

Low-interest loans are lately getting more attention and are available in a number of countries. An owner may combine a grant in addition to tax relief and the remainder in the form of a low-interest loan to cover repair costs. To alleviate cash flow problems, grant awards may also be provided in the form of a short-term loan pending satisfactory completion of works and payment of the award. As in the USA, the low-interest and the guaranteed loans, in addition to grant aid and fiscal incentives, can be used to encourage conservation activity.

\subsubsection{Fiscal incentives}

Fiscal incentives are an effective measure to encourage private investment in the repair and maintenance of architectural heritage buildings by owner-occupiers, ownerinvestors, developers and investors. Providing specific tax incentives for the conservation of architectural heritage buildings in addition to more general urban renewal tax provisions seems to be a superior way of ensuring quality care for the built heritage. Specific architectural heritage funding mechanisms, as used in the USA, which utilize tax incentives, including relief from income tax, property tax, value-added tax (VAT), transfer tax, inheritance tax and capital gains tax, may apply only to the particular taxpaying parties. The low-income owners are forced to either sell their property (which is now lower priced due to bad shape) or to live in bad conditions. Potential unwanted effects of this nature can be resolved by allowing taxexempt entities and low-income owners to receive a higher level of grant assistance, as is the case in the Netherlands.

\subsubsection{Income tax deductions and credits}

The UK government has recently acknowledged that there may be a case for limited relief set against income for private owners for the maintenance of historic buildings, and the case for such incentives has also been made in Canada. Eligibility requirements to enable owners to benefit from income tax deductions vary greatly from county to country with regard to public access requirements, the quality of work undertaken and allowable additional expenses (such as acquisition costs, insurance, alarm installation and provision of modern utilities). Some countries allow additional expenses such as acquisition costs, management expenses for rented property, public liability insurance and alarm installation to be offset against income tax. In the Danish example, evidence is provided that public support for regular maintenance can exclude the need or the necessity for large-scale publicly funded repair projects in the long term.

\section{- Property tax incentives}

In some cases, as in Belgium, Germany, the Netherlands, and the UK, some architectural heritage buildings may be entitled to a property tax exemption, deduction or freeze. These are usually raised at the municipal government level. This principle is usually used in cases of an unoccupied heritage building to claim an exemption.

\section{- VAT/sales tax exemptions and reductions}

The standard EU-defined rate for VAT on the supply of goods and services is from $16 \%$ to $25 \%$. Exemplary are just some cases, such as Denmark and Germany, where VAT concession for works on architectural heritage buildings is not provided. Others, such as Belgium, France, Italy and the Netherlands, have a reduced VAT charge defined. This greatly reduces the cost of works on architectural heritage buildings in residential use. Specifically, in the UK, zero-rated or lower-rate VAT is applied for some works on architectural or protected heritage.

\section{- Donations and sponsorships}

It is not rare that a system of tax deductions for donations is used. Thus, private donations/sponsorship to charitable heritage conservation organizations is encouraged.

\subsubsection{Conservation easement and TDRs}

The donation of a conservation easement to a municipal government or local area-based heritage trust and foundation is particularly important in Canada and the USA, 
where federal and some state/provincial heritage regulatory policy is weak. However, apart from the subjective nature of the market valuation of conservation easement, they are also prone to tax complications. Similarly, TDRs plays an important role in the attempt to discourage demolition of architectural heritage buildings in Canada and the USA. TDRs are only effective in prime locations during a booming property market where a demand for TDRs exists (Pickerall 2009).

\subsection{Tools and regulatory measures}

Firstly, regardless of the location of the heritage buildings, built or architectural heritage is of special interest to the country and the society it represents, and as such, these are to be treated with respect. Therefore, before any works can be undertaken, their scientific, architectural and historic value has to be studied and intervention guidelines requested. Finally, construction works are not to be started or conducted without prior approval of the ministry in charge.

As regulated by the Croatian, Belgian and Greek laws that regulate the protection of heritage buildings, the owner of the building is the sole responsible person for the upkeep of the architectural heritage buildings, but governmental support and partial subsidies can be received for the works needed. These supports and subsidies, in most cases, partially or fully cover just the cost difference of the regular maintenance (in case of a non-heritage building) and the maintenance of the heritage building. These principles apply also in Belgium (Haumont 1992), Greece (Tassios and Chronopoulos 1992), the UK (Sodagar 2013), France and the Netherlands (Pickerall 2009). However, in most cases, aid grant mechanisms are strict and restrictive due to their time limitations and grant application administrative procedures.

Government actions to encourage voluntary repair and maintenance of architectural heritage buildings by owners include regulation. In order to increase the success rate and to ensure private capital flow towards heritage protection, grant aid, low interest loans, tax incentives, easement donations and TDRs can be identified. Various regulatory and funding mechanisms can usually be combined into a more acceptable policy. Most countries combine regulation with the grant aid tool, in addition to some form of additional fiscal incentive.

While similarities exist in the choice of legal framework and funding by governments, variations of subsidy evolvement are found in different countries. As a rule, financial support is provided mainly based upon an agreed plan of works for conservation repair or maintenance works. However, funding for building improvement is never included in these funding types (designated for upkeep of architectural heritage buildings). Generally, the aim seems to be to blend regulatory and funding instruments to create a variety of tools to support private investments in architectural heritage building conservation.

Countries such as Croatia, with low levels of state subsidies for heritage conservation activities, must rely heavily on direct regulation to conserve heritage assets. This strategy is neither popular nor efficient as owners of protected heritage structures must bear the burden of repair and maintenance costs, with little or no compensation from the government. Sanctions, however, for non-compliance with regulatory policies, in most cases, are limited to the use of the architectural heritage buildings, and in reality, authorities are reluctant to use force against private owners without economic compensation and only take action in the most severe cases. In the worst cases, the owner may be expropriated and the building is assigned to a caretaker. Where deliberate neglect of a protected structure (listed building) can be proved in the UK, legislative provision exists for minimum compensation. Following expropriation, buildings may be sold to a Building Preservation Trust for repair.

\section{Comments and further development recommendations (discussion)}

\subsection{On stimulative incentives}

Depending on the political intention and the willingness to invest in heritage preservation and sustainability, different approaches are chosen in different countries.

In the USA, the major problem of cities is that old city cores are depopulating. In order to repopulate and make the city cores socially more interesting, the government of the USA is using TDRs and tax incentives (Cunningham 2008). Thus, the government is avoiding large-scale investments in cultural heritage, but on the other hand, the government cannot achieve the targeted investment areas. This is controlled by sporadic investment incentives, whereby governmental properties are sold at symbolic prices with the contractual obligation of the investor to invest in the renovation and/or upkeep of the whole building. Principles such as tax deductions and TDRs are 
usually appealing just to the large-capital stakeholders, whereas they cannot be appealing to low-income or average-income inhabitants, whereby the regular upkeep of the already inhabited heritage building is set aside.

In Denmark, on the other hand, the proactive policy finances the heritage upkeep by private owners to forestall decay, instead of investing into sporadic repair costs. The policy encompasses income tax relief and is designed to encourage systematic maintenance of architectural heritage buildings. This policy enables the continuous care for the built heritage by the owners themselves, irrelevant of their income. However, in order for this policy to function, the government must be prepared for continuously investing in its heritage.

Research suggests that nationally financed heritage funding initiatives, with clear application and administrative procedures for recipients and the provision of multi-year funding, act as a catalyst to encourage the flow of private sector finance into architectural heritage building conservation projects (Pickerall 2009). In broad terms, in Europe, the emphasis is mainly on statutory regulatory policies. These can usually be allied with direct state provision of grant aid for conservation activities. A number of countries allow additional indirect tax relief and loan guarantees on the portion of non-subsidized costs. In the USA and Canada, however, the historic preservation ordinances are sporadic and mainly formulated as tax incentives to encourage conservation activities.

However, it seems that the majority of governments still have not perceived that preservation of architectural heritage buildings and achieving sustainable development can be, and in a majority of cases are, on the same course to the future stable fiscal and social development of their countries. Therefore, almost no incentives that incorporate structural safety upgrade provisions, as well as sustainable refurbishment or adaptive reuse provisions, can be found.

Although, generally, works on EE and heritage upkeep are stimulated separately, in Europe, the mostly used financial incentive is a financial subsidy or grant. These are generally administered after a complicated administrative procedure with fixed cost and investment plans. As previously mentioned, these are considered to be restrictive by subsidy or grant users. As a better alternative, governmental low-interest, or even no-interest, loans can be provided, as in France. If these are administered through a governmentally owned bank, an additional positive effect is achieved: fiscal stability of the particular governmentally owned bank is increased, and the government itself is publically perceived as proactive and stable (Pickerall 2009).
Additionally, based on the Danish example, for governmentally owned buildings, it is recommended to plan continuous financial support for architectural heritage building upkeep. This can, in most cases, lessen or even avoid the need for large-scale investments for the building repair.

\subsection{On the intervention planning process}

The process of any intervention approval in Croatia and several other EU countries before any such work can be undertaken, as identified during the research conducted as part of the Ph.D. thesis of Sigmund (Sigmund 2014), is shown in Fig. 1.

Normally, the process of renovation, strengthening and refurbishing should be similar to that in new building construction approval; so, when planning the intervention on a historical building, more emphasis should be laid on the preliminary investigation, planning and design.

The preliminary screenings, scope definitions and designs are important phases of the renovation process, as in many countries of the EU, the local government entitled for intervention consent allocation can request architectural and historical study results provided by the consent issuer prior to the intervention guidelines definition. The preliminary architectural and historical study

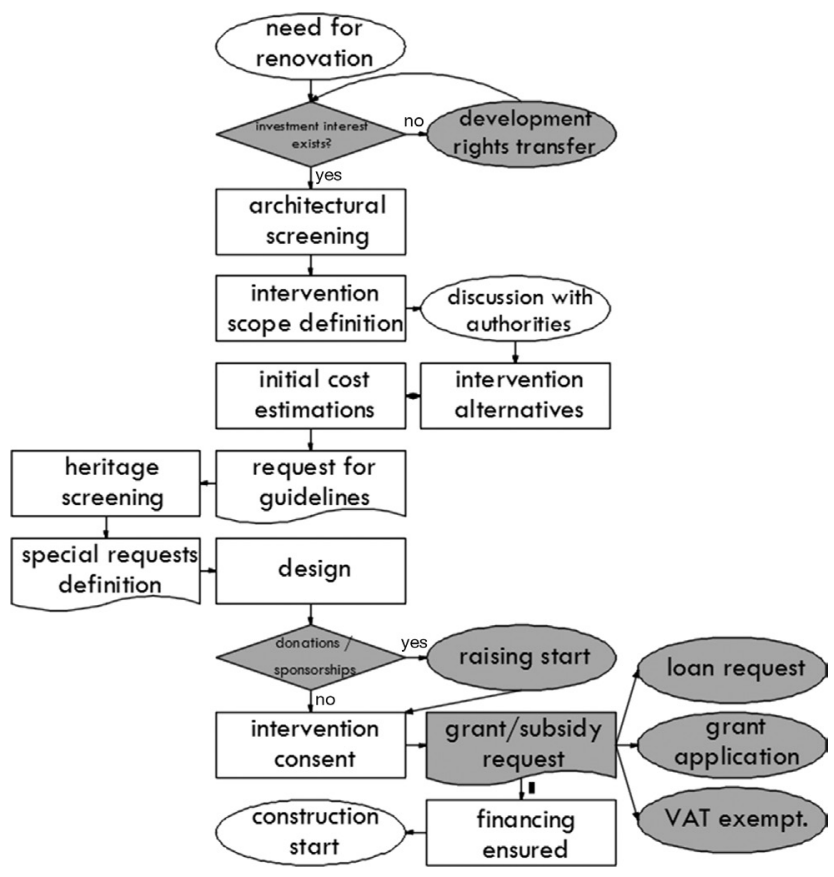

Fig. 1: Intervention preparation process based on Croatian legislative framework (valid in several EU countries). 
provides a wide scope of information such as surveys of the building and its environment (the local context, general impressions, technical status and maintenance status), documentation of user requirements, documentation of property data, contracts that concern the building, history (building year, previous renovations/alterations, users and previous color schemes), as well as drawings and pictures (construction drawings, historical drawings, sketches and photographs). This step cannot be avoided according to the Croatian law. Depending on the intervention plan and the scope of the intended intervention, for each building (existing or non-existing), special requests from the ministry regulating interventions in the physical environment should be issued. Thus, the allowed interventions and scope of works on a building are defined.

The building owner's decision-making process for undertaking renovation differs a lot depending on the reason that gave rise to starting the process. In many cases, it is a question of immediate maintenance, for which the decisions are taken based on the appraisal of options under time constraints, whereas in cases of nonurgent maintenance, cost-benefit analyses are performed. These mainly depend on the defined intervention scope. However, for each planned intervention, a number of intervention possibilities can be listed, which, according to Sigmund (Sigmund et al. 2016), can simply be chosen by an iterative procedure of intervention technique selection and basic cost estimation process (as shown in Fig. 1).

Issuing the guidelines for allowable interventions on architectural heritage buildings can be a time-consuming procedure as these are created for each building separately. The major downside of this procedure is that the guidelines and the protective measures issued can vary from case to case, as they are usually dependent on the professional opinion of the person in charge (Sigmund 2014).

After the designing is done in accordance with special requests from the authority, the intervention design has to be approved by the ministry in charge (by both the ministry regulating interventions in the environment and, if it is a cultural heritage building, the ministry regulating cultural heritage protection).

Finally, the financing options should be chosen based on the intervention scope, investors' willingness to invest in the maintenance and renewal of the property, as well as the property owner.

In cases where the government is the owner of a property, it is not rare that there is a lack of interest in investing for the property upkeep and/or upgrade. If this is the case, the most advisable way to proceed would be to either transfer the development rights or engage in private-public partnership (PPP). However, the selection of the right financing possibility in such cases is up for the owner to select.

If the investment willingness exists, there is no need for TDR and the project development can proceed normally, in accordance with Fig. 1. Generally, the financing can be chosen depending on the existing possibilities. These can be either financial support through grants, subsidies or complete financing through low- or nointerest (or guaranteed) loans. In some cases, the incentives can be combined. However, if the intention is to completely or partially renovate, upgrade or strengthen the built heritage through donations or sponsorship, the fundraising process can begin before the building consent is acquired.

The herein-presented procedure (Fig. 1) can discourage potential investors, especially because in restoration, refurbishment and other works on architectural heritage buildings, policy and political insecurity have proven to be major project risks (Sigmund and Radujković 2016).

If the government seeks to initiate private investments in built heritage or sustainability, financial incentives are not the only measures needed. In addition to financial incentives, a series of non-financial measures are recommended to be used, which can at least ensure a healthy investment environment. It is advised to have clarity in national heritage and development policy. If investments in heritage preservation are expected, simplification of planning procedures and a guaranteed, or at least supported, minimum standard of infrastructure within historic environments are needed. In order to achieve this, governments should have planning procedures and allowed intervention measures defined within the regulatory basics (Sigmund 2014), such as that used in Austria (Bundesdenkmalamt 2011). Thus, the request for intervention guidelines for heritage buildings can be avoided and the guidelines would be common for all cases.

Strong regulatory mechanisms, as in Croatia and Europe in general, on the other hand, are less likely to attract private investment in conservation of the architectural heritage buildings, unless substantial state subsidies are available to alleviate investor's perceived risk.

Finally, the main criticism of the herein-presented financial and non-financial incentives is that none of them stimulate safety-increasing measures when investing in repair, refurbishment or EE. In most cases, heritage buildings are not built to withstand contemporary safety or seismic provisions. As documented, seismic strengthening or safety-increasing measures can, in most cases, cost up to $3 \%-5 \%$ of the general maintenance cost (Sigmund 2014), which is best accomplished when other 
major interventions such as refurbishment or EE interventions are undertaken.

\section{Conclusion}

It seems that the majority of governments still have not perceived that preservation of architectural heritage buildings and achieving sustainable development can be, and in majority of cases are, on the same path to the future stable fiscal and social development of all countries. These rare occurrences of positive support for sustainable development of architectural heritage buildings are evidenced in Germany, the UK, and the Netherlands.

Protection of the built heritage requires a political commitment at a national level through statutory regulations combined with financial support mechanisms and, at a local level, through the integration of municipal conservation activities with the private sector via partnership arrangements. Therefore, prior to adopting proactive and financially demanding incentives, creating a good and healthy investment environment is the priority. These can range from transparent regulatory preservation frameworks and policies, clearly defined development goals, as well as simplified planning-and-execution processes and heritage adaptation-and-refurbishment policies. These measures enable clarity in the investment scopes and risks, disabling unforeseen and unwanted investments or halts during the refurbishment process.

Besides the investment-friendly legal framework, financial incentives are a good investment magnet for private capital. Thus, the investment risk is diminished by various subventions and tax deductions. As popular financial incentives, grants, low-interest loans and guaranteed loans are used. These measures can usually cover from $20 \%$ to $90 \%$ of eligible repair costs and are widely used in the EU. Other widely used financial stress relief measures based on tax incentives are income tax deductions and credits, property tax incentives, VAT and transfer tax reductions, as well as concessions for and exemptions from inheritance tax and capital gains tax. Even though rare, incentives such as conservation easements and TDRs, which are popular in the USA and Canada, might be a good solution for a situation wherein the government seeks to evade large-scale investments. These, however, can mean a complete loss of control over the particular property or the property itself.

Maybe the best and the most far-sighted system of income tax relief for maintenance expenditure on protected structures is that of Denmark. In this example, by the continuous caretaking of architectural heritage buildings, the decay of the heritage is prevented. However, the scheme cannot be used for improvements that would add to the capital value of the property.

As stimulation for non-financial initiative execution, it is advised to have clarity in national heritage and development policy. If investments in heritage preservation are expected, simplification of planning procedures and a guaranteed, or at least supported, minimum standard of infrastructure within historic environments are needed. In order to achieve this, the governments should have planning procedures and allowed intervention measures defined within regulatory basis. Thus, the request for intervention guidelines for heritage buildings can be avoided and the guidelines would be common for all cases. Moreover, the risk of feasibility alterations within the final building consent acquisition process can be avoided.

It is difficult to point out the best financial incentive, as this depends on the governmental decisions and development aims. However, depending on the ownership, willingness to invest and finally the importance of the building to be invested in, the following investment options are suitable:

- If governmentally owned building or property of interest is to be refurbished, upgraded or renovated, yet there is no interest in the government in investments of this kind, the best possible solutions are as follows: a. PPP, whereby the building stays in the ownership of the previous owner (public/government) and the building-generated profit is given to the private investor; b. another well-accepted possibility, TDRs can be pointed out; however, it should be stated that, compared to PPP, in this case, the investor (the party that is on the receiving end of rights transferral) has all rights to do with the building whatever he/she seems fit (as if he/she was the sole owner).

- If the investment willingness exists and the property that is to be invested in has a social importance, a possibility of financing the intended works completely or partially is through sponsorship or donations.

- Independent of the previous two choices, once the building consent is acquired, the following existing financing options can be explored:

$\circ$ As the best non-discriminative financial incentive, governmentally subsidized or guaranteed low- or no-interest loans can be suggested, as used in Germany or the Netherlands. In contrast to other financing principles, governmentally subsidized loans are a great way of stimulating investments independent of the scale of the investment. 
O VAT exemptions are a well-accepted principle to stimulate investments such as built heritage upkeep or sustainable development. The downside of this principle is that it needs to be presumed that the owner of the heritage building has the finances to finance the intervention in the first place. VAT exemptions are, on the other hand, a great principle to stimulate small-scale investments. Thus, the financial support is available without the administrative barriers. This is a well-accepted way of supporting large-scale investment.

- Grants are generally the current principle of incentive support. These are well accepted within the government as well as the user circles, yet, due to the slow processing and administrative hurdles in the acquirement of a grant, grants can be discouraging for small-scale investments.

It is important to point out that a complete financial and legislative framework enabling both architectural preservation and refurbishment (including EE improvements) is missing or extremely rare to be found. As this is the way to sustainable development, maybe this should be the reference point that governments should take into consideration. Additionally, once more, it is of essence to perceive the risk the older buildings can be, unless safety-increasing measures are undertaken in order to bring the older buildings up to date with contemporary safety measures, including resistance to natural and man-made hazards. These interventions are best made when other refurbishment works are undertaken. Using this approach, the cost of these interventions is decreased and the need for additional preparation and repair costs is avoided.

\section{References}

Ashworth, A. (1996). Estimating the life expectancies of building components in life-cycle costing calculations. Structural Survey, 14, pp. 4-8.

Bullen, P. A., \& Love, P. E. D. (2009). Residential regeneration and adaptive reuse: Learning from the experiences of Los Angeles. Structural Survey, 27, pp. 351-360.

Bundesdenkmalamt. (2011). Richtlinie Energieeffizienz Am Baudenkmal. In: Bundesdenkmalamt (ed.). Available at http:// www.bda.at/documents/462396673.pdf, Bundesdenkmalamt.

Cunningham, S. (2008). Rewealth!: Stake Your Claim in the \$2 Trillion Redevelopment Trend that's Renewing the World. McGraw-Hill, New York.

DECC. (2009). Heet and Energy Saving Strategy - Consultation. Department for Energy and Climate Change, London, UK.
Ding, G. (2013). Demolish or refurbish - Environmental benefits of housing conservation. Construction Economics and Building, 13, p. 17.

Dolce, M. (2012). The Italian National Seismic Prevention Program. In: 15th Earthquake Engineering World Conference, Lisbon, 24, 2012.

EERI. (2010). The Mw 7.1 Darfield (Canterbury), New Zealand Earthquake of September 4, 2010. Learning from Earthquakes. Earthquake Engineering Research Institute, USA.

EUPD. (2010). Directive 2010/31/eu of the European Parliament and of the Council of 19 may 2010 on the energy performance of buildings. In: Parliament, E., \& Council, E. (eds.). Available at http://eur-lex.europa.eu/legal-content/EN/TXT/?qid=147 1443453261\&uri=CELEX:32010L0031, Official Journal of the European Union.

EUPD. (2012). Directive 2012/27/eu of the European Parliament and of the Council. In: Parliament, E., \& Council, E. (eds.). Available at: http://eur-lex.europa.eu/LexUriServ/LexUriServ. do?uri=0J:L:2012:315:0001:0056:en:PDF, Official Journal of the European Union.

Haumont, F. (1992). Belgian legislation on the protection of the architectural heritage against disasters. In: The Protection of the Architectural Heritage Against Natural Disasters. Proceedings of the European Colloquy on Regulatory Measures concerning the Protection of the Architectural Heritage against Natural Disasters in Europe (Ravello, Italy, 15-17 November 1989), 6, 1992.

Kim, K. P., \& Park, K. S. (2013). BIM feasibility study for housing refurbishment projects in the UK. Organization, Technology \& Management in Construction: An International Journal, 5, p. 10.

Lorbek, M., Kovačić, I., \& Höflinger, M. (2013). The future of Red Vienna. Portfolio approach to building stocks. In: Hájek, P., Tywoniak, J., Lupíšek, A., Růžička, J., \& Sojková, K. (eds.). Central Europe towards Sustainable Building 2013. Czech Technical University in Prague, Prague, $C Z$.

Lungu, D., \& Arion, C. (2006). Prohitech - intervention strategies. Technical University of Civil Engineering Bucharest, Romania.

Maffei, J., Bazzurro, P., Marrow, J., \& Goretti, A. (2006). Recent Italian Earthquakes: Examination of Structural Vulnerability, Damage, and Post-Earthquake Practices. EERI, USA.

Pickard, R. (2010). European heritage laws and planning regulations: integration, regeneration and sustainable development. In: Guštin, M., \& Nypan, T. (eds.). Cultural Heritage and Legal Aspects in Europe. Institute for Mediterranean Heritage and Institute for Corporation and Public Law Science and Research Centre Koper, University of Primorska, Slovenija.

Pickerall, T. (2009). The Management of Built Heritage: A comparative review of policies and practice in Western Europe, North America and Australia. In: Pacific Rim Real Estate Society - 15th Annual Conference. University of Technology Sydney (UTS), New South Wales, Australia.

Sigmund, Z. (2014). Public buildings seismic vulnerability risk mitigation management model. Ph.D. Doctoral Thesis, University of Zagreb.

Sigmund, Z., \& Radujković, M. (2016). Risk management tool for improving project flows for construction projects on existing buildings. Electronic journal of the Faculty of Civil Engineering Osijek; e-gfos, 12, p. 10. 
Sigmund, Z., Radujković, M., \& Lazarević, D. (2016). Decision support model for seismic strengthening technology selection of masonry buildings. Technical Gazette - Tehnički Vjesnik, 23, p. 10.

Smith, P. F. (2007). Eco-refurbishment: A Guide to Saving and Producing Energy in the Home. Architectural Press, Oxford.

Sodagar, B. (2013). Sustainability potentials of housing refurbishment. Buildings, 3, p. 278.

Tassios, T. P., \& Chronopoulos, M. P. (1992). The Protection of the Greek Architectural Heritage: The Present State of Legal Measures and Experience of their Operations. The protection of the architectural heritage against natural disasters. Proceedings of the European Colloquy on Regulatory Measures concerning the Protection of the Architectural Heritage against
Natural Disasters in Europe (Ravello, Italy, 15-17 November 1989), 14, 1992.

Thomas, S. (2016). Energy Efficiency Policies for Buildings. Wuppertal Institute for Climate, Environment and Energy. Available at: www.cost.eu/download/54802, COST, European Cooperation in Science and Technology.

Warnock, C. (2007). Bringing existing buildings into the sustainability equation. New Zealand Sustainable Building Conference SB07. CIB, Auckland.

Yung, E. H. K., \& Chan, E. H. W. (2012). Implementation challenges to the adaptive reuse of heritage buildings: Towards the goals of sustainable, low carbon cities. Habitat International, 36, pp. 352-361. 